SEBASTIAN LATOCHA

Instytut Etnologii i Antropologii Kulturowej UŁ, Łódź

\title{
ŻYCIE AKADEMICKIE OSÓB JĄKAJĄCYCH SIĘ W PERSPEKTYWIE SPOŁECZNEGO MODELU NIEPEŁNOSPRAWNOŚCI I KONCEPCJI STRUCTURAL VULNERABILITY
}

There was great respect for the verbal professions in those days - the teachers, the clergy, and lawyers. But these seemed to be closed doors because of my stammer. I remember feeling a sense of block to my life (Peter Brown, cyt. za: McDermott 2016, s. 71).

\section{WSTĘP}

Międzynarodowa Klasyfikacja Chorób ICD-10 lokuje jąkanie się pośród „Innych zaburzeń zachowania i emocji rozpoczynających się zwykle w dzieciństwie i w wieku młodzieńczym". Spektrum etiologii niepłynności mowy jest bardzo szerokie; w grę wchodzą czynniki biologiczne, lingwistyczne, psychologiczne i społeczne (Tarkowski, Humeniuk, Dunaj 2010, s. 703-707). Zbigniew Tarkowski dzieli przyczyny jąkania się na wyzwalające czynniki psychofizyczne (m.in. dziedziczność, uraz psychiczny, stres, lęk) oraz utrwalające czynniki społeczne - np. chaotyczna mowa rodziców czy wymagania rodziców, którym dziecko nie jest w stanie sprostać (1992; 2002). „Mamy więc do czynienia z mechanizmem błędnego koła" (Tarkowski 2002, s. 26). Wyróżnia się wiele rodzajów niepłynności mowy, m.in.: przeciąganie głosek; blokowanie głosek; pauzy; rewizje; embolofazje; powtarzanie głosek, sylab, wyrazów; tachylalię; bradylalię (Guitar 2019, s. 131; Tarkowski 1997, s. 137-138). Jąkanie się jako przedmiot badań występuje przede wszystkim na gruncie psychologii i logopedii, które w refleksji nad tym zaburzeniem akcentują terapię i leczenie niepłynności mowy (i to głównie w kontekście dzieci), marginalizując opis samego doświadczenia osób jąkających się i ich illness narratives (zob. Kleinman 1989), czyli ich własnych opowieści o chorobie. Co jednak ważne z perspektywy mojego artykułu - w literaturze psychologicznej i logopedycznej ${ }^{2}$

${ }^{1}$ W moim artykule określenia „jąkanie się”, „zacinanie się" i „niepłynność mowy” stosuję zamiennie, traktując je jako synonimy.

${ }^{2}$ Społeczny aspekt niepłynności mowy dobrze przedstawiły Elżbieta Bijak i Dorota Kamińska. Stwierdziły, że zacinanie się jest tematem tabu nawet wśród logopedów: „Mimo wielu publikacji, przeprowadzonych badań i eksperymentów, mnogości teorii na temat przyczyn i sposobów leczenia jąkania nadal pozostaje ono w pewnym sensie zjawiskiem zagadkowym. Dla jąkających się jest przyczyną problemów w kontaktach interpersonalnych. U rozmówców wywołuje cały wachlarz różnorodnych doznań, które bardzo często nie są dla nich przyjemne. A jakie powoduje reakcje wśród logopedów? Niestety, znaczna grupa logopedów przeżywa swoisty lęk przed tym zaburzeniem mowy i ma poważne trudności w prowadzeniu terapii osób jąkających się" (2013, s. 170-171). 
podkreśla się społeczne konsekwencje niepłynności mowy (Bijak, Kamińska 2013; Błachnio, Przepiórka 2012; Czubara 2009; Guitar 2019), ale problem ten nie był przedmiotem badań poświęconych samemu kontekstowi uczelni. Tymczasem - jak postaram się to udowodnić - moje badania obnażają oralny charakter życia akademickiego, co nie jest sytuacją neutralną dla osób jąkających się. Okoliczność ta stanowi punkt wyjścia dla moich - etnograficznych - badań nad tym zaburzeniem.

Niepłynności mowy nie uznaje się za jeden z culture-bound syndromes - syndromów uwarunkowanych kulturowo (zob. Penkala-Gawęcka 1994, s. 8; Simons, Hughes 1985); to ludzkie zaburzenie występuje na całym świecie, we wszystkich kulturach i rasach, dotyka kobiety i mężczyzn, ludzi młodych i starych, o różnych dochodach, zawodach i IQ (Guitar 2019, s. 5). Na całym świecie jąka się około 50 milionów ludzi (Shell 2005, s. 1). Ilu z nich studiuje lub pracuje na uczelni ${ }^{3}$ ? Ilu z nich tego nie robi, ponieważ się jąka? Pierwsze pytanie przenosi niepłynność mowy z obszaru refleksji nad „zaburzeniami dziecięcymi” w świat problemów osób dorosłych. Pytanie drugie otwiera perspektywę badań i analizy doświadczeń osób jąkających się przez pryzmat kategorii vulnerability i teorii społecznego modelu niepełnosprawności.

\section{RAMY KONCEPTUALNE}

Celem artykułu jest próba odpowiedzi na pytanie, czy mamy do czynienia ze społecznym modelem niepełnosprawności w przypadku sytuacji osób jąkających się, biorących udział w życiu akademickim.

Społeczny model niepełnosprawności to teoria, która upatruje barier związanych z niepełnosprawnością nie tyle w jednostce, ile w społeczeństwie, jego organizacji i instytucjach. W tym sensie kultura jednak warunkuje niepłynność mowy - nie tyle samą obecność (lub brak) zaburzenia, ile jego dotkliwość w pewnych kontekstach, np. edukacyjnym. Anthony Giddens i Philip W. Sutton przeciwstawiają społecznemu modelowi niepełnosprawności model indywidualny, w którego optyce to anormalność jednostki (jako jej immanentna cecha) jest główną przyczyną trudności osób niepełnosprawnych w pełnym uczestnictwie w życiu społecznym (2014, s. 235-236). Społeczny model odwraca ten porządek rzeczy, zastępując koncepcję inwalidztwa jako przyczyny niepełnosprawności perspektywą, że niepełnosprawność jest konstruktem procesu kulturowego i historycznego oraz porządku społecznego (Giddens, Sutton 2014, s. 237). Konsekwencją zmiany modelu z indywidualnego na społeczny jest zmiana optyki z biomedycznej na taką, która nie redukuje niepełnosprawności do pojęć charakterystycznych dla nauk biologicznych (Olivier 1983). Społeczny model niepełnosprawności spotkał się jednak z krytyką, jako że efektem ubocznym tej koncepcji jest marginalizacja przez ten model bolesnych przeżyć osób z niepełnosprawnościami, które to jednak przeżycia są dużą częścią ich doświadczenia (Shakespeare, Watson 2002). Chociaż krytyka ta wydaje się celna, to i tak „[s] połeczny model niepełnosprawności pokazał przede wszystkim, że niepełnosprawność nie jest wyłącznie

${ }^{3}$ W niniejszym artykule określenia „uczelnia”, „akademia” i „szkoła wyższa” stosuję zamiennie. 
kwestią medyczną i należy ją analizować również na gruncie szeroko pojętych nauk społecznych" (Giddens, Sutton 2014, s. 238).

Teorię społecznego modelu niepełnosprawności wzbogaca koncepcja vulnerability (Bankoff 2001). O ile ta pierwsza akcentuje sam mechanizm, który dotyka pewne jednostki i grupy, których cechą jest bycie vulnerable, o tyle ta druga skupia się na doświadczeniu podmiotów vulnerable. Zygmunt Bauman stwierdził, że nie ma w języku polskim słowa, którym da się zastąpić angielskie pojęcie mieszczące w sobie takie konteksty ludzkiej kondycji, jak wrażliwość, podatność na ciosy, niezabezpieczenie, ogólną słabość, brak skutecznej ochrony przed zranieniem, łatwość padania ofiarą czy poddawania się dolegliwościom. „Z braku lepszego terminu” Bauman ukuł pojęcie „ranliwość” (2003, s. 45). Osobami „ranliwymi” - obok noworodków, kobiet $\mathrm{w}$ ciąży, osób starych, $\mathrm{z}$ chorobami rzadkimi, terminalnie chorych, osób z niepełnosprawnościami, osób, które nie znają języka współczesnej medycyny itd. (Rajtar 2020, s. 111) - wydają się właśnie osoby jąkające się, co stwierdzam na podstawie moich badań. Koncepcja vulnerability zajmuje ważne miejsce w refleksji filozoficznej, etycznej, bioetycznej, antropologicznej, socjologicznej oraz na gruncie zdrowia publicznego (Rajtar 2020, s. 108, 112).

Dokładna operacjonalizacja źródeł tej koncepcji, jej teorii i punktów krytycznych znajduje się poza zakresem niniejszego artykułu; kwestie te przedstawiła m.in. Małgorzata Rajtar (2020). Z perspektywy tego tekstu istotny wydaje się, po pierwsze, problem wyzysku, dyskryminacji, stereotypizacji, wykluczenia oraz stygmatyzacji osób, które uznać można za vulnerable (Macklin 2003; Rajtar 2020, s. 111). Po drugie, optyka społecznego modelu niepełnosprawności w życiu akademickim osób jąkających się uwyraźnia elementy structural vulnerability. Podejście to pokazuje, jak „struktury społeczne czynią ludzi chorymi” (Bourgois i in. 2017, s. 299, thumaczenie własne), to znaczy - jak hierarchie społeczne, ekonomiczne i polityczne na poziomie lokalnym oraz relacje władzy zaostrzają m.in. problemy ze zdrowiem jednostek (Bourgois i in. 2017). Pojęcie „strukturalnej ranliwości” w literaturze przedmiotu odnosi się do instytucji i praktyk medycznych, które nieumyślnie zagrażają zdrowiu (Carruth i in. 2021, s. 2); w moim artykule z pomocą terminu structural vulnerability próbuję zbadać udział w tym procesie instytucji edukacji i nauki w złych przeżyciach osób z niepłynnością mowy.

\section{RAMY METODOLOGICZNE}

Artykuł jest efektem badań na temat doświadczenia ${ }^{4}$ osób jąkających się w kontekście życia akademickiego. Od 2019 roku kieruję projektem pt. Obniżona sprawność komunikowania się a studia i praca w szkole wyższej. Etnograficzne badania

4 „Doświadczenie” jest pojęciem głęboko zakorzenionym w humanistyce, gdzie uznaje się je za wieloznaczne i problematyczne (zob. Wolska 2014, s. 95). Ryszard Nycz wyróżnia cztery pola semantyczne „doświadczenia”: 1. poddać próbie, 2. doznać, zaznać, 3. dowieść, udowodnić, 4. okazać, oświadczyć, dać świadectwo (za: Wolska 2014, s. 94). Pole semantyczne „doznać, zaznać” oświetla sens pojęcia „doświadczenie” w moim artykule. 
nad sytuacją osób jąkających się w ramach umowy nr BEA/000047/BF/D z Polskim Funduszem Rehabilitacji Osób Niepełnosprawnych. Informacje o moich badaniach oraz zaproszenie do udziału w nich pojawiły się w prasie, co skróciło i ułatwiło proces rekrutacji ochotniczek i ochotników. Dwa artykuły popularnonaukowe - w lokalnym „Dzienniku Łódzkim” (Kałach 2019) i „Newsweeku” (Burda 2019) - zaprezentowały problematykę moich badań w sferze publicznej. Dzięki pomocy mediów zgłosiły się do mnie osoby, których biografie zrosły się z różnymi uczelniami w kraju i za granicą ${ }^{5}$ a które chciały podzielić się ze mną swoimi przeżyciami poprzez narracje o zaburzeniu.

W toku badań na przełomie lat 2019/2020 przeprowadziłem 20 pogłębionych wywiadów indywidualnych swobodnych $\mathrm{w}$ grupach osób jąkających się: studentów i studentek (6 wywiadów); absolwentów i absolwentek uczelni (6 wywiadów); nauczycieli i nauczycielek akademickich (4 wywiady); oraz wśród kolegów i koleżanek / nauczycieli i nauczycielek jąkających się studentów i studentek (4 wywiady) - w tej grupie rozmówcy nie narratywizowali własnych przeżyć, tylko cudze. Konfrontacja doświadczenia osób niepłynnie mówiących z perspektywą ludzi „z boku” obserwujących ich takie czy inne losy w środowisku akademii jest formą triangulacji metodologicznej (Mason 1996, s.25). W moich badaniach polegała ona nie tyle na wykorzystaniu różnych metod bądź źródeł ${ }^{6}$, ile na metodzie porównywania i analizie przypadków odchyleń (Silverman 2012, s. 262-267). W tym właśnie celu podejmuję próbę „prawdziwego spojrzenia na sytuację w wyniku zespolenia odmiennych perspektyw jej oglądu" (Silverman 2012, s. 260), a nie przedstawiam pełne „historie edukacyjne” dwóch czy trzech osób z niepłynnością mowy. Przedmiotem moich zainteresowań była uczelniana codzienność studiujących i pracujących w szkołach wyższych osób z niepłynnością mowy. Wywiady z jąkającymi się osobami oraz ich znajomymi ze studiów lub z pracy rzuciły światło na wiele problemów w kontekście życia akademickiego, z jakimi borykają się osoby zacinające się. $\mathrm{W}$ projekcie chciałem zbadać $\mathrm{z}$ etnograficzną wrażliwością doświadczenie jąkających się osób w celu weryfikacji hipotezy, że w szkołach wyższych osoby niepłynnie mówiące są wykluczone, a sama instytucja uczelni czyni je structurally vulnerable $\mathrm{i}$,społecznie niepełnosprawnymi”.

Antropologiczne koncepcje i kategorie wypracowane przez Clifforda Geertza, Michaela Herzfelda i Victora Turnera określiły metodologiczny kształt mojego przedsięwzięcia badawczego. W artykule chcę „wyodrębnić materię ludzkich doświadczeń" (Geertz 2005, s. 32), cytując wywiady, które są dla mnie bezcennym źródłem informa-

\footnotetext{
${ }^{5} \mathrm{Na}$ tym etapie badań nie udało mi się włączyć do analizy różnic między kulturami akademickimi w Polsce i za granicą oraz między polskimi ośrodkami akademickimi. W moich badaniach 20 informatorów reprezentowało 9 uczelni. Chcąc zanalizować wpływ kultur akademickich na doświadczenie osób jąkających się i przy tym nie popełnić błędu anegdotyzmu, należy badania kontynuować. Aktualnie, $\mathrm{z}$ racji braku materiału empirycznego, nie sposób problemu tego rzetelnie opracować.

${ }^{6}$ Dane, które analizuję, pochodzą przede wszystkim z wywiadów, które przeprowadziłem podczas badań. Ich etnograficzność opiera się właśnie na metodzie, której elementami są m.in.: praca w terenie, długotrwałe zaangażowanie, personalny i indukcyjny charakter badań (Angrosino 2010, s. 45-46).
} 
cji o problemie stanowiącym przedmiot badań, a nie tylko gwarancją etnograficznego autorytetu (Clifford 2000, s. 29-63). Herzfeld podkreśla zaangażowanie informatorów w praktyki teoretyczne, uprzywilejowując je jako podstawę naszego - antropologów - opisu rzeczywistości społecznej (2004, s. 28).

Przyjęcie postawy antropologa, który $\mathrm{w}$ realiach będących przedmiotem jego badań szuka właściwych kategorii opisu ludzkich przeżyć, pociąga za sobą rezygnację z pojęć dalekich od doświadczenia na rzecz bliskich (Geertz 2005, s. 64). Ja staram się jednak zachować $\mathrm{w}$ artykule równowagę pomiędzy pośrednimi kategoriami, które przedstawiłem jako „ramy konceptualne”, a bezpośredniością illness narratives. Osią konstrukcyjną mojego artykułu są właśnie pojęcia związane z doświadczeniem osób jąkających się, w jakie obfitują wywiady. Jednak deskrypcję i analizę ich przeżyć opieram na teorii społecznego modelu niepełnosprawności oraz koncepcji vulnerability, czyli pojęciach dalekich od ich doświadczenia. Koncepcję antropologii doświadczenia sformułował Victor Turner zainspirowany przez Wilhelma Diltheya teorią przeżycia (niem. Erlebnis) jako odtrutką na strukturalizm w antropologii (Bruner 2011, s. 11-12, 17). Antropologia doświadczenia zajmuje się tym, jak jednostki przeżywają własną kulturę, jak doświadczają samych siebie i własnego życia. W tej optyce na przeżycia składają się nie tylko dane zmysłowe, ale i uczucia oraz oczekiwania. Doświadczenie różni się od zachowania: „To drugie zakłada bowiem istnienie zewnętrznego obserwatora opisującego czyjeś działanie. [...] Przeżycie ma bardziej osobisty charakter, gdyż odnosi się do działającego ja" (Bruner 2011, s. 13). I chociaż zdaję sobie sprawę z tego, że „nigdy nie można w pełni poznać przeżyć kogoś innego” (Bruner 2011, s. 13), to jednak dane są nam ekspresje, czyli „skrystalizowane wydzieliny ludzkiego doświadczenia” (Turner 2005, s. 24), „pojemniki z doświadczeniami innych ludzi" (Bruner 2011, s. 13), a w tym przypadku - illness narratives.

Wszystkie problemy, które sygnalizuję, mogłyby stanowić tematy odrębnych artykułów; niniejszy (pierwszy po badaniach) przedstawia ich panoramę, zaprasza do tematu udziału tradycji akademickich w wykluczeniu osób jąkających się.

\section{KŁOPOTY Z HUMANISTYKĄ}

Jak wynika z materiału empirycznego, niepłynność mowy nie tyle nie pozwala osobom jąkającym aplikować na studia, ile raczej ogranicza - w ich ocenie - ofertę uczelni (liczbę kierunków i tryb studiów), co potwierdza absolwent filologii i historii: Niedostępnych nie ma żadnych, trudne moga być kierunki zwiąane z mówieniem $(\text { AP_06 })^{7}$. Absolwentka administracji dodaje:

Na studia poszłam zaoczne, nie na dzienne, bo wiedziałam, że na dziennych sa egzaminy ustne, ja bym sobie rady nie dała, to by była dla mnie bariera nie do przejścia. Skończyłam wszystkie zaoczne studia, bo wiedziałam, że tam nie ma ustnych egzaminów (AP_03).

${ }^{7}$ Wywiady, jakie przeprowadziłem w ramach badań, znajdują się w archiwum projektu (AP) Obniżona sprawność komunikowania się a studia i praca w szkole wyższej. Etnograficzne badania nad sytuacja osób jąkających się. Wywiady ponumerowałem od AP_01 do AP_20. 
Osoby mówiące niepłynnie, chociaż mogą wybrać właściwie dowolny kierunek studiów (współcześnie w procesie rekrutacji liczą się głównie wyniki egzaminu maturalnego) i w dowolnym trybie, kierują się obrazem studiów humanistycznych, społecznych, aktorskich i tych w trybie dziennym jako „trudnych” - z racji ich oralnego charakteru - dla osób jąkających się. Student dziennikarstwa i komunikacji społecznej mówi:

Ja sam jestem na takich, ale moje studia łączq $w$ sobie także fotografię, grafikę komputerowa $i$ inne zajęcia, które nie wymagaja aż takiej interakcji z prowadzacym, nie wymagaja prezentacji i wystapień publicznych, które sa bardzo stresujące (AP_11).

Absolwentka administracji:

Mnie się wydaje, że humanistyczne są gorsze, bo tam wymaga się erudycji. Skończyć trzeba takie studia na poziomie jakimś, a takiej osobie ciężko jest się wysłowić, a zwieńczeniem kierunków humanistycznych jest umiejętność wysławiania się, a przy fizyce, matematyce jest po prostu rozwiązywanie zadań, umiejętność logicznego myślenia wystarczy, żeby skończyć studia (AP_03).

Oralność i personalność (kontakt z drugim człowiekiem) humanistyki wykluczają, zdaniem badanych, osoby niepłynnie mówiące z tej właśnie części akademickiej agory. Konkretne kierunki - filozofia, etnologia, pedagogika, prawo, administracja, public relations i aktorstwo - informatorzy zaklasyfikowali jako „trudne” (AP_07; AP_16; AP_20), czyli wystawiające na próbę ich „ranliwość”.

Inny obraz - w świetle materiału $\mathrm{z}$ badań - mają studia artystyczne (plastyczne i muzyczne), inżynieryjno-techniczne, ścisłe, przyrodnicze i medyczne. Komunikacja wiedzy w tych obszarach, w odróżnieniu od „zbyt werbalnych” nauk humanistycznych i społecznych, realizuje się przede wszystkim niewerbalnie (np. operacje na liczbach, notacja muzyczna, wzory). Na namalowanym obrazie nie widać, że autor się jąka (AP_11). Absolwentka historii z niepłynnością mowy:

Na kierunkach technicznych jest im łatwej niż na humanistycznych. Na pewno na tych technicznych, mechanicznych większa wage przykłada się do tego, co człowiek robi. Albo plastyczne, artyści maja prościej. Może się nie odzywać, bo jest artysta. Że ja na to nie wpadłam wcześniej! Mogłam być artystką! A humanistyka jest związana $z$ mówieniem, $z$ wypowiadaniem się, z umiejętnościq dyskutowania. Na przykład informatyka, siedzisz i klepiesz w klawiaturę (AP_04).

Jąkająca się studentka psychologii zwróciła uwagę na fakt, że niepłynność mowy śmieszy innych ludzi:

Kierunki artystyczne mogłyby trochę ułatwić sprawę, natomiast ścisłe to już totalnie. Wydaje mi się, że nawet jakby nic człowiek nie mówił, to i tak, jak zna wzór, to już dobrze. Bym jeszcze mocno dorzuciła informatykę na przykład, grafikę i tak dalej, bo te kierunki, jakby ich ta praca sama, ta praca tez w sumie nie wymaga kontaktów z ludźmi. Myślę, że osoba, która się jąka, a ma takie zainteresowania czy zdolności, to śmiało może iść na taki kierunek, bo tam właśnie jest praca z komputerem, bo komputer cię nie wyśmieje, jak się zająkniesz (AP_02).

A śmieszność (jako rodzaj deformacji obrazu jednostki) jest pierwszym mechanizmem kulturowego procesu mityzacji obcych (Bystroń 1935). Praca z komputerem, $\mathrm{z}$ aparaturą techniczną, $\mathrm{z}$ instrumentem muzycznym nie pociąga za sobą ryzyka 
tego mechanizmu, kontakt z drugim człowiekiem - niestety tak. Historia edukacyjna absolwentki kilku kierunków inżynieryjno-technicznych stanowi przykład tego, jak niepłynność mowy wpływa na wybór kierunku studiów:

Ja skończyłam w sumie trzy kierunki. Najpierw skończyłam inżynierię zarządzania, zarządzanie i inżynieria produkcji, później na czwartym roku poszłam na drugi kierunek, na mechatronikę. I skończyłam sobie jeszcze magisterkę z transportu. Jestem umyst ścisty. My mamy bardziej kontakt ze sprzętem, z liczbami niż z ludźmi. Jak miałam sześć, siedem lat, myślałam, żeby zostać aktorka. I przez kilka lat to było moje marzenie. Ja się zaczęłam jąkać od dziesiatego roku życia. [...] A przez pierwsze trzy lata podstawówki byłam bardzo aktywna. Wszystkie spektakle, przedstawienia. I gdzieś tam mi się marzyła właśnie kariera aktorska, ale jąkanie jednak wyklucza (AP_09).

$Z$ jednej strony, informatorzy niejako antycypują własne wykluczenie na podstawie supozycji o oralnym charakterze humanistyki. $Z$ drugiej strony, w optyce społecznego modelu niepełnosprawności oralność i ważki udział kontaktu z drugim człowiekiem (jako elementy wyróżniające humanistykę na tle całego „świata nauki”) ograniczają zakres życia akademickiego osób jąkających się; werbalne oblicze studiów humanistycznych, społecznych i aktorskich wydobywa na światło dzienne „ranliwość” niepłynnie mówiących osób - w tym przypadku structurallly vulnerable.

\section{TRADYCJE DYDAKTYCZNE}

O ile kwestia stereotypu humanistyki jako „zbyt werbalnej” podkreśla strukturalny wymiar wykluczenia zacinających się osób studiujących lub pracujących w uczelni, o tyle sprawa akademickich tradycji dydaktycznych oświetla aspekt wykluczenia studentów i studentek z niepłynnością mowy przez samych nauczycieli i nauczycielki.

Skostnienie i tradycjonalizm dydaktyki, afirmacja hierarchicznego modelu relacji na linii mistrz-uczeń są częścią współczesnej rzeczywistości uczelni. Nauczyciel akademicki, który wziął udział w badaniach, podzielił się narracją na temat swojego jąkającego się studenta, który w obliczu braku tolerancji dla jego zaburzenia zniknął $\mathrm{z}$ akademii:

Dlaczego odszedt? No bo zauważyt, że sa tacy ludzie, którzy maja do niego nieodpowiedni stosunek, źle go oceniaja. To jest bardzo wrażliwy chłopak, przyjąt taka strategię, że on odchodzi, tlumaczac to tym, że dostał pracę. Musiał to jakoś zracjonalizować, bat się widocznie albo wstydzit się powiedzieć, że on odchodzi przez pewne osoby. Przez to, że te osoby roztaczaja wokót siebie taka aurę grozy niekiedy, strasznej powagi, a to był na tyle wrażliwy człowiek, że nie potrafit sobie z tym problemem poradzić, mimo że ja staratem się mu pomóc. Za to też ustyszałem jakieś tam komentarze, że za bardzo się anga$\dot{z} u j e ̨$. No i jakoś tak się zaprzyjaźniliśmy, że ja się staratem głównie dla niego zaprowadzić takie jakby nieformalne stosunki na tym seminarium. Robitem im zawsze herbatę, rozmawialiśmy sobie i on pomału zaczat się otwierać. On się przeniósł do mnie [na zajęcia]. [...] No i on do mnie przyszedt i stopniowo on się jakoś przyzwyczait do mnie, to trwało $z$ dwa miesiace może, ale pod koniec tego seminarium on byt $w$ stanie prawie, prawie normalnie rozmawiać, on się zacinat, jąkał się, ale był w stanie wypowiedzieć zdanie, dwa zdania, trzy zdania i jaką́s dłuższa wypowiedź był w stanie z siebie wydobyć (AP_19).

Z całej palety dydaktycznych sytuacji „trudnych” dla osób jąkających się na studiach egzamin ustny (AP_01; AP_02; AP_03; AP_09) oraz „plusy za aktywność” 
zajmują miejsce pryncypalne: Moge przeczytać wymagane teksty, teksty dodatkowe, posiadać ogromna wiedza na dany temat, ale boję się zgtosić, bo czuję, że $w$ trakcie zacznę się jąkać (AP_11). Absolwentka historii uświadomiła mi, że społeczny wymiar niepłynności mowy pociąga za sobą bariery ekonomiczne:

Na ćwiczeniach trzeba było się odzywać, bo za aktywność byly plusiki i z tych plusików później była wystawiana ocena. [...] Dla mnie dużym problemem było to, że na zajęciach trzeba było samemu wyjść z inicjatywa, podnieść rękę i się zgłosić. To było dla mnie najtrudniejsze, żeby po prostu tę barierę przeskoczyć, którą sobie sama dałam, że trzeba się odezwać. Bardzo mocno się przykładałam do tych zajęć. Olbrzymia wiedzę z nich mam. To była historia średniowiecza. Dostawałam, gdzieś tam zdarzyło się dostać plusa, bo byto pytanie o datę na przykład, więc ja po prostu coś krótkiego, nie jakaś dłuższa wypowiedź. Byłam w stanie jakoś to przejść, ale jechałam po prostu na trójach naciaganych. I na tych trójach jechałam i stypendium nie było przez to. Mogłam starać się o stypendium, ale wiedziałam z góry, że mam dużo trój, to raczej nic $z$ tego nie będzie (AP_04).

Narracja ta jest wyraźnym przykładem structural vulnerability w kontekście życia akademickiego jąkających się studentów i studentek.

Egzamin ustny, „plusy za aktywnośc”, anachroniczna relacja między mistrzem i uczniem należą do dydaktycznych „świętych” tradycji uczelni i obyczajowości akademickiej, które mają - jak się okazuje - charakter wykluczający. Materiał z badań, który obfituje w narracje o bolesnych przeżyciach studentów i studentek z niepłynnością mowy, demaskuje „oczywistość” tych praktyk. Na tej podstawie zgadzam się z Joanną Hańderek, która konstatuje, że:

Wykluczenie wypływające z obyczajowości i utartych praktyk jest równoznaczne z kwestionowaniem odmienności i różnorodności postaw. Obyczajowość i utarte praktyki często wiążą się z postawą traktującą kulturę jako drugą naturę, a więc zakładającą, iż obyczajowość jest czymś naturalnym, oczywistym, a jej zaprzeczanie wiąże się z łamaniem praw natury. Dlatego ludzie podważający porządek obyczajowości są piętnowani najsilniej w tych społeczeństwach, które utarte praktyki traktują jak świętość (2017, s. 23).

\section{WYMIARY WYKLUCZENIA STUDENTÓW I STUDENTEK}

Jąkający się studenci i studentki nie biorą pełnego udziału w życiu akademickim i jego towarzyskich kontekstach. Studentka pedagogiki z niepłynnością mowy stwierdziła, że jej zaburzenie przeszkadza w nawiązywaniu kontaktu $z$ innymi studentami (AP_01). Osoby jąkające się dotyka problem samowykluczenia, czyli sytuacji, w której podmiot zamyka się w sobie, wycofuje się z relacji społecznych, ponieważ doświadcza ostracyzmu. Samowykluczenie to psychiczna reakcja jednostki na wykluczenie, ratunek wobec niego (Hańderek 2017, s. 28-29). Ilustracją tego procesu w kontekście życia akademickiego jest narracja studenta dziennikarstwa i komunikacji społecznej:

Zdarza się, że czuję się wykluczony, choć to ja sam się alienuję. Nie chcę, żeby ludzie widzieli, jak się zacinam, nie potrafię czegoś powiedzieć. Dość ciężko nawiązać mi bliższe znajomości, dlatego trzymam się swojej ścisłej grupy. Nie należę też to żadnego koła naukowego. Bardzo chciałem przyłaczyć się do telewizji uniwersyteckiej, ale to trudne w moim przypadku. W akademickim centrum kultury 
organizowane sa slamy poetyckie i choć piszę, to bardzo rzadko występuję. Nieważne jak dobry jest wiersz, jeśli autor zatnie się w połowie czytania, albo zacznie się jąkać, to każde, nawet najpiękniejsze słowa, traca swój wydźwięk (AP_11).

Na ważny wymiar wykluczenia zwróciła uwagę koleżanka jąkającego się studenta:

Prosit od nas kogoś albo wykładowcę, by na przykład czytał jego prezentację, która przygotowat. Ale też myślę, że zlecając komuś przeczytanie czyjejś prezentacji, warto to kontrolować $w$ takim sensie, by osoba, która taka prezentację czyta, nie zdominowała jej swoim zdaniem, bo takie też były sytuacje. Obraz wyglądał tak, że na rzutniku była przygotowana prezentacja przez niego, a osoba, która ja odczytywała, większa część wystąienia stanowit komentarz osoby odczytujacej cudza prezentacje. Więc jakby tak teraz sobie myślę, że jąkanie wyklucza, bo nawet czasem nie da rady się sprzeciwić, [...] odciąć się komuś albo jakoś wejść w nurt dyskusji, a w kostkę nie kopniesz każdego (AP_08).

Studentka psychologii: Osoby, które się jąkają, najbardziej właśnie nie lubią, jeżeli ktoś zaczyna zdanie i chce je wypowiedzieć do końca, a ktoś skończy za niego zdanie po prostu za niego mówi (AP_02). Jąkanie się wyklucza z pełnego udziału w grupie towarzyskiej mówiącej płynnie, a przez to wpływa na liczbę koleżanek i kolegów ze studiów, ogranicza udział w kołach naukowych i innych akademickich strukturach. Osoby zacinające się, radząc sobie z zaburzeniem, upraszczają leksykę swoich prezentacji publicznych (AP_04; AP_09; AP_11), przez co łamią reguły wspólnego języka - żargonu danej dziedziny wiedzy. Marc Shell podkreśla, że mowa jest znakiem charakterystycznym dla istot ludzkich, a mowa w konkretnym języku świadczy o przynależności do określonej grupy ${ }^{8}$ (Shell 2005, s. 50). Wywiady, które przeprowadziłem w toku badań, pokazują, w jaki sposób w życiu akademickim - na różnych jego poziomach - tak czy inaczej jąkającym się studentom i studentkom odbiera się część człowieczeństwa. Magdalena Środa przypomina, że brak mowy jest wskaźnikiem obcości. „Trudno nawiązać z nim [obcym] kontakt, bo jest pozbawiony mowy. Nie mówi, lecz bełkocze" (Środa 2020, s. 91). Dlatego sposób, w jaki uczelnia w gorsecie tradycji akademickich „odbiera mowę" jąkającym się osobom, bliski jest społecznemu modelowi niepełnosprawności i koncepcji structural vulnerability.

\section{WYMIARY WYKLUCZENIA NAUCZYCIELI I NAUCZYCIELEK}

Inne problemy w życiu akademickim mają jąkający się studenci i studentki, a inne - jąkający się nauczycielki i nauczyciele, którzy muszą zmierzyć się ze stereotypem akademika u samego progu kariery:

Mój kolega, już zmarly, wysokiej klasy specjalista, profesor zwyczajny, jąkał się. Kariera akademicka niezwykła, ale jakie problemy były, że go zatrudnić na uczelni w ogóle, to głowa mała. Jednak jąkała nie mieści się we wzorze pewnym akademika, uczonego (AP_12).

${ }^{8}$ Shell aforystycznie konstatuje: „1. Jeśli w ogóle nie potrafisz mówić, prawdopodobnie nie jesteś ludzką istotą. 2. Jeśli jakoś mówisz, wówczas możesz być istotą ludzką, ale równie dobrze papugą. 3. Jeśli nie posługujesz się moim językiem, w sposób, jaki znam, wówczas prawdopodobnie nie jesteś członkiem mojego plemienia" (Shell 2005, s. 5, tłum. własne). 
Potwierdził to inny mówiący niepłynnie nauczyciel akademicki:

Najbardziej przeszkadza mi to, że mój zawód nie przewiduje takich potknięć, że doktor, profesor to przede wszystkim nienaganna kultura języka, której częścią jest piękna dykcja, a nie zacinanie się. [...] Jąkanie się z gruntu odbiera powage, majestat i dorosłość, kojarzy się z dziecinnością. Jakby godziło w samo serce godności uczelni i życia akademickiego. [...] Co to za doktor, który się jąka? Jąkanie jakby ośmieszało ten zawód (AP_10).

W tej optyce niepłynność mowy nie mieści się w stereotypie naukowca, który godnie reprezentuje majestat uczelni.

Dla absolwenta filologii i historii z epizodem pracy w szkole wyższej udział w konferencjach naukowych był doświadczeniem traumatycznym:

Najgorsze było na konferencjach, kiedy miałem przeczytać referat albo przedstawić wyniki badań. Spinałem się $i$ jedno zdanie czytałem z minutę, jak na górę wspinając się na każdą kolejna sylabę. Na jednej konferencji, w której uczestniczyli zaproszeni naukowcy, zapytatem o coś występującego, który mi odpowiedział, ale $w$ trakcie zadawania pytania poczułem czyjąś rękę na ramieniu i zirytowany głos - Nie mogłeś swojego pytania napisać? - Nie obrócitem się, by się nie zdenerwować jeszcze bardziej (AP_06).

Będący manifestacją akademickiej tradycji konferencyjny reżim - czasowy i retoryczny („krótko, atrakcyjnie i na temat”) - stoi w sprzeczności z ideą równości wszystkich osób referujących.

\section{NIEPŁYNNOŚĆC MOWY A NIEPEŁNOSPRAWNOŚĆ}

Nauczyciel jąkającego się studenta:

Ale na pewno nie sa to osoby pelnosprawne, bo jest pewna bariera $w$ komunikowaniu się. Uczelnia nie stwarza odpowiednich do tego możliwości, żeby te osoby mogły normalnie studiować (AP_19).

Z jednej strony, opinia ta mogłaby stanowić potoczną definicję społecznego modelu niepełnosprawności na przykładzie niepłynności mowy, z drugiej zaś - podkreśla płynny status osób zacinających się w oczach społeczeństwa i ich egzystencję nie „w”, ale „pomiędzy” kulturowymi taksonomiami. Wobec tego niepłynność mowy jawi się jako zaburzenie graniczne między zdrowiem a chorobą, między pełnosprawnością a niepełnosprawnością. Jak wspomniałem, jąkanie się występuje w klasyfikacji ICD-10, ma swój kod: F98.5, ale należy do „Innych zaburzeń zachowania i emocji [...]", co - według mnie - świadczy o tym, że zaburzenie to nie daje się zaszeregować bez problemu. Ponadto, z medycznego portalu internetowego, współfinansowanego przez Europejski Fundusz Rozwoju Regionalnego, można dowiedzieć się, że jąkanie się „[p]owinno być klasyfikowane jako zaburzenie tylko wtedy, jeśli jego stopień w wyraźny sposób upośledza płynność mowy" $\mathrm{Z}$ tego wynika, że stopień zacinania się decyduje o tym, czy mamy do czynienia z zaburzeniem, czy z czymś innym. Pytanie pierwsze: $Z$ czym? Pytanie drugie: Kto i jak definiuje ten stopień oraz jaki jest

${ }^{9} \mathrm{http} / / /$ www.onkologia-online.pl/icd10/show/2578,jakanie_(zacinanie_sie), data dostępu: 20.06.2021 
w tym udział czynników społecznych i kulturowych? ${ }^{10} \mathrm{Z}$ jednej strony, brak określonego w stratyfikacji społecznej klarownego statusu osób jąkających pozwala na analizę i interpretację tego przypadku w przez pryzmat antropologicznej koncepcji „brudu” Mary Douglas (2007, s. 45-49, 77-81). „Brud to produkt uboczny systematycznego porządkowania i klasyfikacji rzeczy" (Douglas 2007, s. 77). Z drugiej strony, osoby z niepłynnością mowy przypominają kulturowych innych (Benedyktowicz 2000; Stomma 2002), którzy stanowią część społeczeństwa, ale egzystują na jego peryferiach, poza uniwersalnością normy; innych, którzy są - jak pisze Środa - „nie tak” i „nie dość” (2020, s. 11). Przekładając to na realia codzienności - osoby jąkające się, z jednej strony, wyklucza się z pewnych sfer życia osób mówiących płynnie (są nie dość pełnosprawni), z drugiej zaś - nie mogą liczyć na orzeczenie o stopniu niepełnosprawności (są nie dość niepełnosprawni). Dlatego jest to wykluczenie podwójne ${ }^{11}$.

Osoby jąkające się przedstawiają jednak skrajne opinie w tej materii; jedne chciałyby, żeby niepłynność mowy kwalifikowała je do orzeczenia o stopniu niepełnosprawności, drugie wolałyby uniknąć symbolicznej stygmatyzacji. Zwolenniczką uznania jąkania się za rodzaj niepełnosprawności była absolwentka administracji:

Ja uważam, że to jest jakaśniepetnosprawność, a tego nie ma wogóle nigdzie, że to jest osoba niepełnosprawna. Ja mam orzeczenie o niepetnosprawności, ale na depresję, ale nie dlatego, że ja się jąkam, a ja naprawde uważam, że to jest osoba niepelnosprawna, ma utrudniony kontakt ze światem, we wszystkim, bo jednak się mówi i tym się różnimy od zwierząt. Dzięki mowie możemy się rozwijać, a tutaj jesteśmy zablokowani na amen, nie możemy wyrażać siebie, wszystkim jest mowa dla człowieka. Jąkanie przekreśla wszystko naprawdę (AP_03).

Argumentacja studentki psychologii sprzeciwiającej się uznaniu niepłynności mowy za niepełnosprawność:

Mnie się wydaje, że to by było stresujace, poza tym jeszcze bardziej chyba by przekonywało o tym, że to jest jakiś, nie wiem, jak jakaś niepetnosprawność, a nie wydaje mi się, żeby osoby jąkajace się chciały tak się czuć (AP_02).

\section{NIEPŁYNNOŚĆ MOWY A KONCEPCJA RESILIENCE}

Choroby, zaburzenia i inne stany jednostkowe mają swoje ciemne (ból, cierpienie) i jasne strony (przyjemność) (Gert, Culver, Clouser 2009, s. 177-224; Szubert 2011). „W istocie wielu ludzi choruje, wcale źle się nie czując, a wielu chorych czuje się nawet lepiej niż w stanie normalnym" (Gert, Culver, Clouser 2009, s. 179). Ta uwaga $\mathrm{w}$ świetle materiału z badań - wydaje się aktualna. Optyka społecznego modelu niepełnosprawności w kontekście niepłynności mowy eksponuje kwestię elementów resilience $\mathrm{w}$ doświadczeniu osób z tym zaburzeniem. Koncepcja resilience - ogólnie

\footnotetext{
${ }^{10}$ Por. uwagi na początku artykułu dotyczące uwarunkowania kulturowego.

${ }^{11}$ A przecież na podstawie takiego orzeczenia osoby zacinające się mogłyby skorzystać z szeregu przywilejów określonych w Ustawie z dnia 27 sierpnia 1997 r. o rehabilitacji zawodowej i społecznej oraz zatrudnianiu osób niepełnosprawnych (Dz.U z 2018 r. poz. 511 ze zm.).
} 
rzecz biorąc - odnosi się do dynamicznego procesu adaptacji i dobrego przystosowania się jednostki wobec przeciwności losu, traumatycznych przeżyć i zagrożenia rozwoju psychofizycznego (Borucka, Ostaszewski 2008; Luthar, Cicchetti 2000; Rutter 2000). Jąkanie się można zaliczyć właśnie do takich przeciwności losu.

Wpływ na poziom resilience mają takie czynniki, jak: cechy indywidualne (np. optymizm, poczucie humoru, pozytywny obraz własnej osoby), cechy rodziny (np. dobry status ekonomiczny rodziny, pozytywne relacje z członkami rodziny), cechy społeczności lokalnej (m.in. wysoki poziom bezpieczeństwa, niski poziom przemocy), cechy polityki i kultury społeczeństwa (np. dbałość o opiekę zdrowotną i edukację) (Wright, Masten 2005). Chociaż nie badałem wpływu tych czynników na adaptację moich informatorów w środowisku akademii, to wywiady pokazały wyraźnie, że osoby jąkające się przystosowują się do życia w uczelni, rozpoznając nawet korzystne aspekty niepłynności mowy. Absolwent filologii i historii:

Nie wykluczam, że to dzięki jąkaniu postuguję się językami obcymi oraz mam stuch do różnych akcentów. Jąkanie generalnie staram się odbierać jako przeszkodę, która potencjalnie mnie robi silniejszym (AP_06).

Studentka psychologii sądzi, że niepłynność mowy rozwija zmysł obserwacji i sztukę słuchania:

Na pewno jak się człowiek jąka, to ma przez to, że właśnie mniej mówi i tak się wycofuje, mniej mówi, to na pewno dużo więcej obserwuje, na pewno dużo stucha i to ma też pozytywny aspekt, bo ktoś w sumie jest dobrym słuchaczem, a takich naprawdę mało (AP_02).

A właśnie sztuka słuchania stanowi bezcenną kompetencję w dziedzinie komunikacji międzyludzkiej (Kępiński 2012). Kaeven Lemay w książce What You Can Learn from a Stutterer tłumaczy, jak niepłynność mowy kształtuje charakter jednostki. Lemay twierdzi, że człowiek uczy się, słuchając, a nie mówiąc; dzięki temu - jego zdaniem - osoby jąkające nie mają problemów z nauką. Niepłynność mowy uświadamia również, że każde słowo na swoją wartość (2017, s. 18-26).

\section{KONKLUZJE}

Zgadzam się z Barrym Guitarem, który twierdzi, że niepłynność mowy ma charakter powszechny (jej proweniencja jest biologiczna, nie kulturowa), ale społeczeństwa i kultury różnią się stopniem akceptacji jąkania się (Guitar 2019, s. 121). Z moich badań wynika, że „świat akademii” stanowi przykład „subkultury”, w której niepłynność mowy leży poza granicami społecznej normy, gdzie jest rodzajem inności pociągającej za sobą określone konsekwencje, które przedstawiłem na podstawie opisu doświadczeń osób biorących udział w badaniach. Sprowadzają się one głównie do różnych rodzajów wykluczenia: samowykluczenia, wykluczenia „uczniów” przez ich „mistrzów”, wykluczenia na podstawie obyczajowości i utartych praktyk czy wykluczenia antycypującego. 
Guitar podkreśla, że dorosłe osoby jąkające się, a takie były moimi informatorami, czują bezsilność, frustrację, złość i rozpacz w sytuacjach społecznych, na studiach, w pracy $(2019$, s. 8,147$)$. Moje badania to potwierdziły. Tradycjonalizm podkreślający „święty” majestat uczelni czy też troska o jakość dydaktyki wykluczają w stopniu, który opisałem, osoby niepłynnie mówiące z pewnych wymiarów egzystencji w ramach szkoły wyższej. Dzięki badaniom wyszły na jaw konteksty pozwalające stwierdzić, że ich „niepełnosprawność” w życiu akademickim jest rodzajem structural vulnerability oraz społeczną konstrukcją będącą efektem ubocznym skostniałości dydaktyki i kanałów komunikacji, które stoją na straży „tradycji akademickiej”. O ile niepełnosprawność fizyczna jest problemem, z którym uczelnie jednak radzą sobie (lepiej lub gorzej), o tyle niepłynność mowy wydaje się problemem peryferyjnym w kontekście polityki różnorodności w szkole wyższej. Z badań wynika, że tradycje akademickie mają charakter wykluczający, a funkcjonowanie uczelni opiera się na oralności. W związku z tym to instytucja czyni pewne jednostki i grupy niepełnosprawnymi i vulnerable.

Projekt został sfinansowany ze środków Państwowego Funduszu Rehabilitacji Osób Niepełnosprawnych, przyznanych na podstawie decyzji BEA/000047/BF/D.

Państwowy Fundusz

Rehabilitacji Osób

Niepełnosprawnych

\section{LITERATURA}

Angrosino Michael 2010, Badania etnograficzne i obserwacyjne, tłum. M. Brzozowska-Brywaczyńska, Wydawnictwo Naukowe PWN, Warszawa.

B a n k off Gre g or y 2001, Rendering the World Unsafe: Vulnerabillity as Western Discourse, Disasters, $\mathrm{nr} 25$ (1), s. 19-35.

B a u m a Z Zyg m unt 2003, Żyjąc (czasami umierając) na tłocznej planecie, Przegląd Socjologiczny, nr 52 (2), s. 35-51.

B e nedykt ow ic z Z bigniew 2000, Portrety „Obcego”. Od stereotypu do symbolu, Wydawnictwo Uniwersytetu Jagiellońskiego, Kraków.

Bijak Elżbieta, Ka mińska D or ot a 2013, Społeczny aspekt jąkania. Wskazówki dla jąkających się i ich rodziców, Logopedia Silesiana, nr 2, s. 168-180.

Błachnio Agata, Przepiórka Aneta 2012, Jąkanie jako zaburzenie z perspektywy psychologicznej: przegląd badań, Psychologia Jakości Życia, t. 11, nr 2, s. 211-222.

Borucka Anna, Krzyszt of Ostaszewski 2008, Koncepcja resilience. Kluczowe pojęcia i wybrane zagadnienia, Medycyna Wieku Rozwojowego, t. 12 (2), s. 587-597.

Bourgois Philippe, Holmes Seth M., Sue Kim, Quesada James 2017, Structural Vulnerability: Operationalizing the Concept to Address Health Disparities in Clinical Care, Academic Medicine, nr 92 (3), s. 299-307. doi:10.1097/ACM.0000000000001294.

B r u ne r E d w ard M. 2011, Przeżycie i jego ekspresje, [w:] V.W. Turner, E.M. Bruner (red.), Antropologia doświadczenia. Z epilogiem Clifforda Geertza, tłum. E. Klekot, A. Szurek, Wydawnictwo Uniwersytetu Jagiellońskiego, Kraków, s. 11-39. 
B u rda Kat ar z yn a 2019, Przełamać blokadę, Newsweek, nr 39, s. 81-82.

Bystroń Jan Stanisław 1935, Megalomania narodowa, Towarzystwo Wydawnicze „Rój”, Warszawa.

Carruth Lauren, Martinez Carlos, Smith Lahra, Donato Katharine, Piñ ones-Rivera Carlos, Ques ad a Ja mes 2021, Structural Vulnerability: Migration and Health in Social Context, BMJ Global Health, 6:e005109. doi:10.1136/bmjgh-2021-005109.

Cliff ord Ja me s 2000, Kłopoty z kulturą. Dwudziestowieczna etnografia, literatura i sztuka, tłum. E. Dżurak i in., Wydawnictwo KR, Warszawa.

C z u b a r a To m a s z 2009, Społeczne konsekwencje jakania, Wydawnictwo Ardius, Warszawa.

D o ugla s Mary 2007, Czystość i zmaza, tłum. M. Bucholc, Państwowy Instytut Wydawniczy, Warszawa.

G e e r $\mathrm{z}$ Cli f ford 2005, Wiedza lokalna. Dalsze eseje z zakresu antropologii interpretatywnej, thum. D. Wolska, Wydawnictwo Uniwersytetu Jagiellońskiego, Kraków.

Gert Bernard, Culver Charles M., Clouser K. Danner 2009, Bioetyka. Ujęcie systematyczne, tłum. M. Chojnacki, Wydawnictwo słowo/obraz terytoria, Gdańsk.

Giddens Anthony, Sutton Philip W. 2014, Socjologia. Kluczowe pojęcia, tłum. O. Siara, P. Tomanek, Wydawnictwo Naukowe PWN, Warszawa.

Guita r B arry 2019, Stuttering: An Integrated Approach to Its Nature and Treatment, Wolters Kluwer, Philadelphia.

H a ń d e r e k J o a n n a 2017, Wokół wykluczenia, [w:] J. Hańderek, N. Kućma (red.), Wykluczenia, Ośrodek Badawczy Facta Ficta, Kraków, s. 15-34.

Herzfeld Michael 2004, Antropologia. Praktykowanie teorii w kulturze i społeczeństwie, tłum. M.M. Piechaczek, Wydawnictwo Uniwersytetu Jagiellońskiego, Kraków.

Kała ch Ma ci e j 2019, Łodzianin szuka osób, które się jąkają, by badać ich problemy, Dziennik Łódzki, nr 215, s. 6.

Kę p i ń s k i Ma r c i n 2012, Sztuka słuchania, sztuka mówienia. Miejsce i rola absolwentów kierunków humanistycznych w public relations, Etnografia Polska, t. 56, z. 1-2, s. 117-134.

K le in m a A A th u r 1989, The Illness Narratives: Suffering, Healing, and the Human Condition, Basic Books, New York.

L e m a y K e ve n 2017, What You Can Learn from a Stutterer, CreateSpace Independent Publishing Platform.

Luthar Suniya S., Cicchetti Dante 2000, The Construct of Resilience: Implication for intervention and Social Policies, Development and Psychopathology, nr 12, s. 857-885.

Macklin Ruth 2003, Bioethics, Vulnerability, and Protection, Bioethics, nr 17 (5-6), s. 472-486.

Mas on J e n if e r 1996, Qualitative Researching, Sage, London.

Mc D e r m o t t G e r a ld R. 2016, Famous Stutterers, Cascade Books, Eugene.

Olivi e r Mich a l 1983, Social Work with Disabled People, Macmillan, Basingstoke.

Pe nka la-Gaw ę cka D a n u ta 1994, Antropologiczne spojrzenie na chorobę jako zjawisko kulturowe, Medycyna Nowożytna, nr 1-2, s. 5-16.

R a j t a r M ałg o r z a t a 2020, The Concept of Vulnerability within Research Ethics and Health Policies on Rare Diseases, Przeglad Socjologiczny, nr 69 (3), s. 107-127. Doi.org/10.26485/PS/2020/69.3/5.

Rutter Mich a el 2000, Resilience Reconsidered: Conceptual Considerations, Empirical Findings and Policy Implications, [w:] J.P. Shonkoff, S.J. Meisels (red.), Handbook of Early Child Intervention, Cambridge University Press, New York-Cambridge, s. 651-681.

Shakespeare Tom, Wat son Nicholas 2002, The Social Model of Disability: An Outdated Ideology, Research in Social Science and Disability, nr 2, s. 9-28.

S h ell Mar c 2005, Stutter, Harvard University Press, Cambridge.

Silverman David 2012, Prowadzenie badań jakościowych, tłum. J. Ostrowska, Wydawnictwo Naukowe PWN, Warszawa.

Simons Ronald C., Hughes Charles C. 1985, The Culture-Bound Syndromes, D. Reidel Publishing Company, Dordrecht. 
St om ma Ludwik 2002, Antropologia kultury wsi polskiej XIX wieku oraz wybrane eseje, Piotr Dopierała, Łódź.

S z u b e r t M a t e u s z 2011, O „przyjemności” chorowania, [w:] K. Łeńska-Bąk, M. Sztandara (red.), O rozkoszach wszelakich... Od przyjemności do ekstazy w kontekstach kultury (Stromata Anthropologica, nr 7), Wydawnictwo Uniwersytetu Opolskiego, Opole, s. 115-125.

Środ a Magd a le n a 2020, Obcy, inny, wykluczony, Wydawnictwo słowo/obraz terytoria, Gdańsk. Tarkowski Zbigniew 1992, Jąkanie wczesnodziecięce, WSiP, Warszawa.

Tarkowski Zbi gn i ew 1997, Klasyfikacja niepłynności mówienia, Audiofonologia, nr 10, s. 137-143. Tarkowski Zbigniew 2002, Jąkanie, Wydawnictwo Naukowe PWN, Warszawa.

Tarkowski Zbigniew, Humeniuk Ewa, Dunaj Jolanta 2010, Jąkanie w wieku przedszkolnym: przegląd badań, Psychiatria Polska, t. 44, nr 5, s. 703-712.

Turn e r Vict or 2005, Od rytuatu do teatru: powaga zabawy, tłum. J. Dziekan, M. Dziekan, Oficyna Wydawnicza Volumen, Warszawa.

Ustawa z dnia 27 sierpnia 1997 r. o rehabilitacji zawodowej i społecznej oraz zatrudnianiu osób niepełnosprawnych (Dz.U z 2018 r. poz. 511 ze zm.).

Wolsk a D o r ot a 2014, Doświadczenie, [w:] M. Saryusz-Wolska, R. Traba (red.), Modi memorandi. Leksykon kultury pamięci, Wydawnictwo Naukowe Scholar, Warszawa, s. 94-99.

Wright M. O'Dougherty, Masten Ann S. 2005, Resilience Processes in Development: Fostering Positive Adaptation in the Context of Adversity, [w:] S. Goldstein, R.B. Brooks (red.), Handbook of Resilience in Children, Kluwer Academic/Plenum, New York, s. 17-37.

\section{SEBASTIAN LATOCHA}

\section{ACADEMIC LIFE OF STUTTERING PERSONS \\ IN THE PERSPECTIVE OF THE SOCIAL MODEL OF DISABILITY AND THE CONCEPT OF STRUCTURAL VULNERABILITY}

Key words: stuttering, exclusion, vulnerability, social model of disability, university, disability studies, medical anthropology, Poland

Stuttering is a speech disorder that affects approximately 50 million people worldwide. It makes everyday life difficult not only for children but also for adults. In psychology and speech therapy the social aspects of stuttering are emphasized, but so far this problem has not been studied in the context of academic life. My research is devoted to this issue in Poland I analyze the academic life of people who stutter through the prism of the social model of disability, the category of structural vulnerability, and exclusion. This study revealed the orality of the universities and a number of academic traditions based on well-established practices and social structures that make stuttering students and academic teachers vulnerable or socially disabled.

Dane Autora:

Dr Sebastian Latocha

Instytut Etnologii i Antropologii Kulturowej Uniwersytetu Łódzkiego

ul. Lindleya 3/5, 90-131 Łódź

E-mail: sebastian.latocha@uni.lodz.pl

ORCID: https://orcid.org/0000-0003-4226-9131 